\title{
Um estudo das emoções em crônicas jornalísticas
}

\section{A study about emotions in journalistic chronicles}

Lúcia Helena Martins Gouvêa

Universidade Federal do Rio de Janeiro

lhluar@yahoo.com.br

Resumo: O presente artigo constitui-se em um estudo sobre o conceito de pathos aplicado a crônicas jornalísticas de autoria de Luiz Garcia e publicadas pelo jornal O Globo, do Rio de Janeiro. O pathos, segundo Aristóteles, é um meio de prova derivado da emoção despertada pelo orador nos ouvintes. Patrick Charaudeau, linguista em cuja teoria este trabalho se fundamenta, trata o fenômeno como uma categoria de efeito. Este artigo, portanto, considera o pathos como o efeito produzido pelo locutor no auditório. Como, para o linguista, o interesse da disciplina Análise do Discurso, com relação a esse conceito, está em estudar o processo discursivo por meio do qual as emoções se desencadeiam, este trabalho tem como objetivo analisar as estratégias linguístico-discursivas usadas pelo cronista a fim de atuar sobre o auditório, provocando-lhe determinadas emoções com potencial para persuadi-lo. As emoções, à semelhança do conteúdo informativo dos enunciados, são consideradas importantes meios de persuasão. Alguns estudos desenvolvidos por Christian Plantin, sobre o tema, também serão levados em conta.

Palavras-chave: efeitos visados; procedimentos linguístico-discursivos; argumentação; persuasão.

Abstract: The present article is a study on the concept of pathos applied to journalistic chronicles authored by Luiz Garcia and published by the newspaper O Globo, from Rio de Janeiro. The concept of pathos, according to Aristotle, is an evidence derived from the emotion aroused 
by the speaker in the listeners. Patrick Charaudeau's theory, on which this work is based, analyzes this phenomenon as an effect category. This article, therefore, considers the concept of pathos as the effect produced by the speaker in the audience. As to the linguist the interest of Discourse Analysis, with respect to this concept, is to study the discursive process through which emotions are triggered, this study aims to examine the linguistic-discursive strategies used by the chronicler to act on the audience, causing them certain emotions with the potential to persuade them. Emotions, like the informative content of statements, are considered important means of persuasion. Some studies by Christian Plantin on the subject, will also be taken into account.

Keywords: intended effects; linguistic and discursive strategies; argumentation; persuasion.

Recebido em: 31 de maio de 2016.

Aprovado em: 17 de agosto de 2016.

\section{Introdução}

Este artigo tem como proposta apresentar uma pesquisa de pósdoutoramento que estuda o conceito de pathos em crônicas jornalísticas. Trata-se de um trabalho que tem como corpus crônicas de Luiz Garcia publicadas no jornal O Globo, do Rio de Janeiro, nos anos de 2011, 2012 e 2013.

O objetivo é mostrar uma possibilidade de estudo da subjetividade em gêneros opinativos, sob os pontos de vista argumentativo e persuasivo. Para isso, serão considerados os estudos de Patrick Charaudeau sobre pathos, estudos em que ele opera com a patemização como uma categoria de efeito e analisa a organização do universo de patemização.

Com a finalidade de analisar, então, o efeito que o locutorcronista produz no auditório ( pathos), serão observados os procedimentos linguístico-discursivos que possibilitarão a identificação desse efeito visado. Vale dizer, serão analisadas algumas estratégias linguísticodiscursivas empregadas pelo locutor para atuar sobre o alocutário, estratégias essas que permitirão reconhecer as intenções do sujeito da 
enunciação e vislumbrar as possíveis consequências no que diz respeito ao público-alvo.

Algumas abordagens de Christian Plantin, sobre a temática, também contribuirão, assim como o tratamento dado por Oswald Ducrot, Jean Claude Anscombre e Ingedore Koch a marcas linguísticas da enunciação, e o comportamento de Kerbrat-Orecchioni quanto ao conceito de modalização.

\section{Pressupostos teóricos}

Para falar de pathos, recorre-se à abordagem de alguns autores, iniciando-se pela Retórica de Aristóteles (2012). Segundo ele, a Retórica é uma forma de argumentação, é a arte genuína de argumentar e funda-se em provas, em meios de persuasão.

São dois os meios de prova: o meio não artístico, que se constrói por intermédio da evidência de testemunhos ou de contratos escritos; e o meio artístico, que corresponde aos meios de persuasão engendrados pelo orador.

A este trabalho, interessam os meios artísticos de prova, que, para Aristóteles, se dividem em três categorias: o logos, o ethos e o pathos.

O logos diz respeito aos meios derivados de argumentos verdadeiros ou prováveis, vale dizer, corresponde ao conteúdo proposicional dos enunciados. $\mathrm{O}$ ethos é um meio de prova derivado do caráter do orador, isto é, designa a imagem projetada pelo locutor através de seu discurso. O pathos, tema deste artigo, é um meio de prova derivado da emoção despertada pelo orador nos ouvintes, ou seja, é um tipo de prova que recorre aos sentimentos dos ouvintes, afetando-os de tal sorte que eles passem a aderir mais facilmente às teses propostas pelo orador.

Segundo Chabrol (2000, p. 112), o ethos e o pathos são indispensáveis no processo da argumentação, na medida em que o objetivo comunicacional não é somente fazer saber do ponto de vista cognitivo, mas também fazer gostar ou fazer tocar para persuadir ou convencer.

Para Charaudeau (2007), criador da Semiolinguística do Discurso, o pathos é um conceito que exige um tratamento especial, razão por que adotou o termo patemização ao estudar as emoções no discurso. Segundo ele, a patemização é uma categoria de efeito, o que leva a se considerar, neste artigo, o pathos como o efeito produzido pelo locutor no auditório. 
Pergunta-se, entretanto, como é possível investigar a emoção que se está produzindo no auditório, isto é, no "conjunto daqueles que o orador quer influenciar com sua argumentação" (PERELMAN, 1996, p. 22), seja pelo discurso oral, seja pelo escrito. Sabe-se que entrar em contato com ouvinte ou com o leitor não é exatamente possível, mas uma forma de investigar o efeito que se pretende produzir é analisar as estratégias linguístico-discursivas empregadas pelo locutor para atuar sobre o alocutário.

Charaudeau (2000, p. 136) diz que o interesse da disciplina Análise do Discurso, com relação ao conceito de pathos, está em estudar o processo discursivo por meio do qual as emoções se desencadeiam. Para isso, é importante entender o tratamento dado por ele $(1992,2008)$ aos "atos enunciativos", tratamento de acordo com o qual as modalidades, em sentido amplo, dividem-se em alocutivas, elocutivas e delocutivas.

Para Charaudeau, as modalidades alocutivas caracterizam-se por implicar o locutor e o interlocutor, mais precisamente a maneira pela qual o locutor impõe um comportamento ao interlocutor. Nesse quadro, estão inseridas algumas modalidades, dentre as quais a da sugestão ou conselho, como pode ser observado neste exemplo colhido do corpus, o qual, vale lembrar, constitui-se de crônicas de um único autor - Luiz Garcia:

Não se esqueçam: ao contrário do que muita gente pensa, banqueiro também pode ir para a cadeia — onde os únicos bancos são de madeira dura (Agora, bancos de madeira, 06/08/2013).

As modalidades elocutivas, por seu turno, não envolvem o interlocutor no ato locutivo. Elas dizem respeito à maneira pela qual o locutor revela seu ponto de vista sobre aquilo que enuncia. Dentre algumas delas, encontra-se, no corpus, um exemplo que reúne as modalidades da possibilidade e da convicção:

[...] não posso garantir, mas aposto que nunca antes $[\ldots]$ o mais alto tribunal mandou para a cadeia [...] um grupo tão numeroso de cidadãos que, alguns anos atrás, mandaram e principalmente desmandaram (A turma da $\operatorname{tog} a, 16 / 11 / 2012$ ). 
Por fim, as modalidades delocutivas são desligadas do locutor e do interlocutor, no sentido de o discurso não apresentar marcas de $1^{\mathrm{a}}$ ou $2^{\mathrm{a}}$ pessoas. A proposta emitida existe em si mesma e se impõe aos interlocutores em seu modo de dizer. São duas as modalidades delocutivas: a da asserção, com suas variantes - dentre elas a modalidade da probabilidade, no exemplo (1) abaixo -, e a do discurso relatado - no exemplo (2).

(1) Três diretores do Rural receberam penas de prisão: Kátia Rabello e José Roberto Salgado, 16 anos e 8 meses; e Vinicius Samarane, oito anos e 9 meses.

Parece justo - como castigo para a trinca e como exemplo para outros cidadãos espertos do mundo financeiro. (Agora, bancos de madeira, 06/08/2013).

(2) Há poucos dias, o presidente do Senado, José Sarney, disse num discurso que a universalização da saúde pública ainda é um desafio para o Brasil. (Saudáveis senadores, 27/03/2012)

Como, de acordo com Charaudeau, quando os indivíduos interagem verbalmente, isso ocorre por meio de construções envolvendo locutor e interlocutor, somente locutor, ou não envolvendo nenhum dos dois, é possível entender que o estudo do pathos, como um efeito visado, direcione-se às estratégias linguístico-discursivas usadas para emocionar o interlocutor ou o auditório.

O efeito patêmico, para o linguista, pode apresentar uma dupla enunciação: uma enunciação da expressão patêmica e uma enunciação da descrição patêmica.

A enunciação da expressão patêmica caracteriza-se por ser simultaneamente elocutiva ("estou furioso") e alocutiva ("não fique furioso") e tem por objetivo provocar um efeito de patemização tanto pela descrição ou manifestação do estado emocional do locutor, quanto pela descrição do estado emocional em que o outro deveria encontrar-se.

Imagine-se uma cena em que um pai, olhando para o filho de modo sério, diz a ele: - estou furioso! Provavelmente, essa elocução provoque um sentimento de medo no menino. Por outro lado, na mesma cena, poderia ocorrer de o filho olhar para o pai e dizer: - Não fique furioso, papai! Essa outra elocução poderia causar, no pai, por exemplo, um sentimento de arrependimento. 
A enunciação da descrição patêmica é delocutiva ("a multidão está furiosa") e tem como característica propor, ao interlocutor, ${ }^{1}$ a narrativa de uma cena dramatizante capaz de produzir um efeito patêmico. A partir de uma cena em que duas amigas conversam e uma narra momentos de tensão por que passara, dizendo "a multidão estava furiosa", a elocução poderia produzir na outra um sentimento de perplexidade.

Em se tratando de marcas verbais que provocam efeitos patêmicos, Charaudeau observa que tanto o emprego de certas palavras pertencentes a um universo emocional (indignação, felicidade; reconfortante, reprovável; suavizar, irritar) quanto o emprego de palavras não relacionadas a esse universo (manifestação, bombardeio; roxo, grande; escrever, organizar) podem produzir um efeito patêmico. Isso significa que o efeito visado pode partir de um discurso explícito e direto ou de um discurso implícito e indireto.

Visualizem-se duas cenas em que a primeira se constitui de dois velhos amigos conversando, e a segunda, de duas colegas de trabalho confabulando. Na primeira cena, um narra ao outro o seguinte: - Ele só me disse palavras reconfortantes. Na segunda, uma diz a outra: $-\mathrm{O}$ chefe chegou com o olho roxo! Os sentimentos produzidos, na sequência, podem ter sido de alívio e de preocupação, emoções despertadas pelo adjetivo "reconfortante", cuja própria tonalidade é patêmica, e pelo adjetivo "roxo", palavra que não descreve emoção.

$\mathrm{O}$ efeito patêmico ainda pode depender das inferências que os parceiros do ato comunicativo podem fazer, do seu conhecimento de mundo e do conhecimento da situação de enunciação. $\mathrm{O}$ efeito patêmico não será o mesmo se se narrar que "um homem pobre ganhou a loteria" ou que "um homem rico ganhou a loteria". No primeiro caso, a enunciação poderá provocar um comentário do tipo "Que maravilha!", comentário que será a expressão de um sentimento de alegria. No segundo, poderá suscitar um comentário do tipo "Que absurdo!", comentário que significará a expressão de um sentimento de indignação. O contexto e a situação de emprego das palavras são determinantes para o efeito que produzirão.

\footnotetext{
${ }^{1}$ Neste trabalho, determinados vocábulos como ouvinte, interlocutor, alocutário, auditório - embora isoladamente não sejam sinônimos - estão sendo usados com o sentido de reunião de pessoas a quem o locutor objetiva atingir com seu discurso, seja por intermédio da oralidade, seja por meio da escrita.
} 
Charaudeau apresenta suas propostas sobre o estudo do efeito patêmico, declarando que esse efeito está atrelado a três tipos de condições.

A primeira condição diz que o discurso produzido deve-se inscrever em um dispositivo comunicativo em que a finalidade e os lugares que são atribuídos previamente aos parceiros de troca favorecem o surgimento de efeitos patêmicos. Dessa forma, os dispositivos da comunicação científica, didática e dos debates de tipo colóquio de peritos não se predispõem ao surgimento desses efeitos, comparando-se com os dispositivos da comunicação ficcional, da comunicação midiática (caso das crônicas jornalísticas, cujo estudo foi proposto pelo projeto de pósdoutorado) e das discussões polêmicas, que são altamente favorecedores. É importante destacar que não há discurso completamente neutro, já que, por trás dele, existe sempre um sujeito. O que há são discursos prototipicamente predispostos a provocar efeitos patêmicos e outros não.

A segunda condição a que o efeito patêmico está atrelado diz respeito ao campo temático sobre o qual se apoia o dispositivo comunicativo. O tema deve prever a existência de um universo de patemização e propor certa organização das tópicas aptas a provocar o efeito patêmico. Para o discurso midiático, as tópicas da "desordem social" ou de sua "reparação", por exemplo, são produtoras dos efeitos visados. Já para o discurso publicitário, as tópicas que se predispõem são a da "felicidade" e a do "prazer".

A terceira condição a que o efeito patêmico está ligado determina que a instância de enunciação se valha de uma mise en scène discursiva com visada patemizante (cf. CHARAUDEAU, 2004, p. 23), ou seja, a enunciação deve envolver uma encenação discursiva que trabalhe para um fazer crer e um fazer sentir.

Assim, segundo Charaudeau, para que o discurso seja patemizante, é indispensável que ele se inscreva num dispositivo comunicativo determinado, esteja relacionado a certas temáticas e explore a mise en scène discursiva própria da emoção.

Ainda sobre o conceito de pathos, é importante registrar algumas abordagens de Plantin (2010) acerca do assunto.

Plantin diz que os linguistas que trabalham com as emoções valem-se não só do léxico das emoções (substantivos, verbos, adjetivos) como também dos enunciados de emoções, vendo estes como uma consequência daquele. Como exemplo, ele apresenta os enunciados "João 
despreza o dinheiro" e "O dinheiro enoja João", cujos verbos denotam sentimentos e cujo experenciador ocupa, no primeiro caso, a posição de sujeito e, no segundo, a posição de objeto. Quanto aos enunciados de emoções, ele diz tratar-se de enunciados-conclusões, isto é, enunciados que surgem a partir de uma argumentação, como exemplifica o diálogo que se segue:

X: O novo prédio da prefeitura é o mais bonito da região, estou tão orgulhoso!

Y: Quando penso em tudo que poderia ter sido feito pelos moradores de rua da comunidade com o dinheiro gasto nesse prédio, tenho vergonha! (PLANTIN, 2010, p. 61)

Segundo o linguista, o enunciador é a entidade que experencia algo, e as emoções vividas por ele são as mesmas vividas pelo sujeito falante. Assim, quando Luiz Garcia verbaliza o enunciado (1) "Os números são assustadores" - ao relatar que 711 menores haviam sido detidos por prática de violência e que nos três primeiros meses do ano haviam sido registrados 1.505 estupros (Guerra cívica, 10/05/2013)-ele experencia um sentimento de horror.

Quando, porém, diz “Esse precedente, felizmente, não impediu que o secretário de segurança, J.M.B., esteja procurando uma forma legal de investigar a situação financeira dos policiais civis e militares do Estado do Rio" (Na hora certa, 04/10/2011) - ao tratar da necessidade de os funcionários do Estado revelarem seus bens antes de assumirem um posto - ele experencia um sentimento de felicidade.

Outros linguistas também são considerados para a pesquisa da temática em apreço, na medida em que apresentam trabalhos importantes sobre marcas linguísticas da enunciação. Trata-se de marcas linguísticodiscursivas por intermédio das quais se pode identificar a subjetividade do locutor e, consequentemente, as suas intenções e os efeitos que quer produzir no alocutário.

Assim, observam-se, por exemplo, os operadores argumentativos, estudados profundamente por Ducrot e Anscombre, e revistos por outros linguistas, como Koch no Brasil.

Segundo Anscombre e Ducrot (1977, p 27), a descrição semântica de um enunciado não deve restringir-se ao seu conteúdo informativo, mas levar em conta também as indicações relacionadas à utilização desse enunciado visando a um determinado tipo de conclusão. 
Para os linguistas, estão presentes, na maioria dos enunciados, certas marcas que determinam o seu valor pragmático, independentemente de seu conteúdo informativo. Essas marcas são elementos da gramática tais como quase, apenas, ao menos, até, inclusive, mas, embora, portanto, já que etc; todas indicando a força argumentativa dos enunciados e, por essa razão, denominadas operadores argumentativos.

Os operadores argumentativos, então, são marcas linguísticas da enunciação, o que significa dizer que delineiam o caminho argumentativo dos enunciados, representando a intenção com que estes são produzidos.

A intenção, o tempo, o lugar, os interlocutores, as relações sociais, isto é, as condições de realização dos enunciados são constitutivas de seu sentido. Esse fato indica que os operadores argumentativos constituem marcas de subjetividade no discurso, à semelhança de outras tais como "é claro que", "pode ser que" etc. Assim, compreendem-se os operadores como traços de modalização cujo uso funciona como estratégia argumentativa capaz de causar determinados efeitos no alocutário. Dessa forma, são eles considerados, na pesquisa, como índices de patemização.

Outro caminho linguístico-discursivo que conduz à identificação do pathos está no trabalho com atos de modalização. Koch (2011) diz que um locutor, na realização de seu discurso, manifesta suas intenções e suas atitudes diante dos enunciados que produz por meio de atos ilocucionários de modalização. Esses atos se atualizam por intermédio de vários modos de lexicalização, como verbos performativos (Eu te proíbo de falar nesse assunto), advérbios modalizadores (Provavelmente ele chegue hoje), orações modalizadoras (É possível que isso aconteça) e operadores argumentativos (Embora ele seja displicente, fez o que lhe pedi).

Segundo a autora (2011, p. 86), a utilização das modalidades tem por função (a) marcar o maior ou menor grau de engajamento do locutor em relação ao enunciado que produz; (b) deixar claros os tipos de atos que o locutor deseja realizar, e fornecer, ao interlocutor, pistas quanto às suas intenções; (c) permitir a introdução de modalizações efetuadas por outras vozes incorporadas ao seu discurso; e (d) possibilitar a construção de um panorama do evento histórico que é a produção do enunciado. Assim, por intermédio de marcas linguísticas de modalização, é possível realizar um estudo de identificação do pathos relacionado ao locutor.

Kerbrat-Orecchioni (1980, p. 43) também estuda marcas linguísticas da enunciação. A autora encara a enunciação como 
um fenômeno cuja característica básica é a utilização de diversos procedimentos linguísticos que marcam a presença do locutor no enunciado, revelando o seu posicionamento em relação ao conteúdo informativo. Alguns desses procedimentos constituem justamente o que se chamam modalizadores e termos avaliativos, verdadeiras marcas de subjetividade no enunciado.

No que diz respeito à subjetividade modalizante, KerbratOrecchioni (1993, p. 168) diz que funcionam, como modalizadores, expressões que especificam o modo de asserção como constativo, hipotético, obrigatório. Veja-se a modalidade do obrigatório representada no enunciado de Garcia "O bafômetro tem de ser, democraticamente, igual para todos" (O bafo de todos, 09/10/2012). Também desempenham a função de modalizadores expressões que especificam o modo das proposições enunciadas (Falou rapidamente sobre o assunto) e o grau de adesão do sujeito da enunciação com relação ao conteúdo afirmado. Observe-se a modalidade da certeza no enunciado de Garcia "É certo que, na sociedade em que vivemos, homofobia e racismo não são considerados virtudes" (O preço da igualdade, 12/04/2013), por ocasião da reflexão do cronista sobre projetos de lei e comissões que analisam os projetos, sendo presidente de uma das comissões um deputado acusado de homofobia e racismo.

Quanto à subjetividade avaliativa, a linguista diz que o valor axiológico de um termo requer que se considere o contexto verbal e o que se acredita saber sobre a ideologia do locutor.

Em relação ao objeto que é avaliado positiva ou negativamente, deve-se levar em conta a fonte avaliativa, bem como o grau de intensidade com que se formula a avaliação. Um caso bastante produtivo é a utilização de expressões axiológicas superlativas tais como "profundamente injusta", "altamente eficaz". O uso de adjetivos (atitude decente), substantivos (Eles têm escrúpulos, sim!) e verbos (O estudante equivocou-se) que expressam a avaliação do locutor também é um procedimento comum, segundo Kerbrat-Orecchioni.

Como se verifica, existem diversas formas linguísticas que expressam a subjetividade do locutor e produzem um efeito visado por ele. $\mathrm{O}$ estudo dessas marcas linguístico-discursivas torna possível a identificação do pathos em crônicas de Luiz Garcia, textos que formam o corpus da pesquisa desenvolvida. 
Veja-se, a seguir, a análise do corpus, a qual é apresentada por intermédio das hipóteses que nortearam o trabalho, da sua confirmação por meio de gráficos, dos exemplos, bem como do comentário a respeito destes.

\section{Resultados da pesquisa}

Analisando-se o corpus da pesquisa, cujos textos foram publicados ao longo dos anos de 2011, 2012, 2013, constatou-se que Garcia tratou de quinze temáticas, a saber: justiça, política, ética, mídia, religião, contravenção, corrupção, educação, carnaval, segurança, turismo, economia, violência, trabalho e morte.

No que concerne aos critérios de análise das crônicas, levaramse em conta estratégias de patemização relacionadas aos conceitos apresentados, há pouco, nos pressupostos teóricos. São estas as estratégias: palavras/expressões que desencadeiam emoção; expressões modalizadoras; princípio de avaliação; enunciados que podem produzir efeitos patemizantes; princípio da classificação, enumeração ou quantidade; princípio de proximidade ou distanciamento; palavras que descrevem de modo transparentes emoções; topoi; verbos que selecionam emoção; palavras que designam calamidade; menção a situações vividas; termos de cores; e termos de emoção descritiva.

Vale destacar algumas características do gênero crônica jornalística, na medida em que ele se insere no dispositivo comunicativo midiático, o qual, como disse Charaudeau, é um dispositivo que se predispõe à produção de efeitos patêmicos. Vejam-se as palavras de Costa, abaixo, acerca da crônica:

[...] é feita com uma finalidade utilitária e predeterminada: agradar aos leitores dentro de um espaço sempre igual e com a mesma localização, criando-se, assim, no transcurso dos dias ou das semanas uma familiaridade entre os escritos e aqueles que o leem. [...] O estilo deve dar a impressão de naturalidade, e a língua escrita aproximar-se da fala. [...] É a pausa de subjetividade ao lado da objetividade da informação do restante do jornal. [...] A crônica nos obriga à síntese, à capacidade de condensar emoções em parágrafos-barragem. (COSTA, 2009, p. 79-81) 
Levando-se em conta, então, que a crônica jornalística visa a agradar o leitor, estabelecendo uma familiaridade com ele por meio de um estilo livre - o que significa caracterizar-se pela subjetividade -, entende-se que é um gênero que explora a capacidade de emocionar. Observe-se o trabalho com as hipóteses.

Inicia-se a análise, considerando-se a primeira hipótese, segundo a qual o efeito patêmico se apresentaria tanto por meio de uma enunciação da expressão patêmica (alocutiva e elocutiva) quanto por meio de uma enunciação da descrição patêmica (delocutiva), havendo, porém, predomínio desta. A hipótese se confirmou, como pode ser constatado no gráfico a seguir:

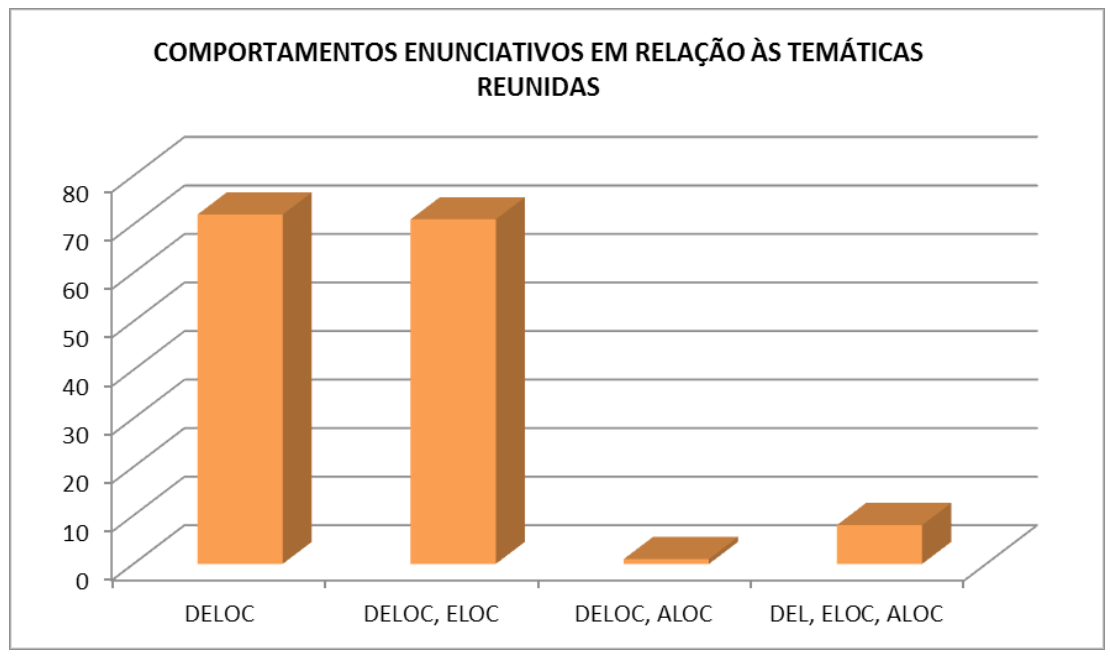

Gráfico 1

A partir desse gráfico (1), que representa os comportamentos em relação às temáticas reunidas, verifica-se uma pequena diferença entre os dois primeiros grupos (delocutivo $\mathrm{X}$ delocutivo e elocutivo) e uma diferença imensa entre os dois primeiros e os dois últimos (delocutivo e alocutivo X delocutivo, elocutivo e alocutivo). São 72 crônicas construídas somente pelo comportamento delocutivo, $69 \mathrm{com}$ os comportamentos delocutivo e elocutivo, 1 com os comportamentos delocutivo e alocutivo e 8 com os comportamentos delocutivo, elocutivo e alocutivo. 
A hipótese de que o efeito patêmico se apresentaria predominantemente pela enunciação da descrição patêmica (comportamento delocutivo) foi levantada pelo fato de se constatar que Garcia é um cronista cujos textos se aproximam mais da formalidade comparando-se com outros cronistas -, apesar do gênero descontraído que é a crônica. Dessa forma, seria natural que predominasse o comportamento delocutivo, aquele em que o sujeito da enunciação se apaga, no sentido de não ocorrerem explicitamente marcas de $1^{\mathrm{a}}$ ou de $2^{\mathrm{a}}$ pessoas do discurso. Veja-se este exemplo:

"Seria salutar que todos os partidos exigissem de suas bancadas que nenhum de seus membros assinasse qualquer documento sem lê-lo primeiro." (Ler primeiro, 14/08/2012)

Este é um exemplo cujo texto é construído por meio de uma enunciação da descrição patêmica, isto é, constrói-se unicamente pelo comportamento delocutivo, já que não foram usadas marcas de $1^{\mathrm{a}} \mathrm{ou}$ $2^{\text {a }}$ pessoas do discurso. Vale destacar, entretanto, que a ausência dessas marcas apenas camufla a subjetividade do locutor, pois ela continua existindo. Seria salutar na opinião de quem? Na opinião do cronista, é claro.

Houve efetivamente o predomínio da enunciação da descrição patêmica, e a diferença mínima - 72 crônicas com o comportamento somente delocutivo e 69 com delocutivo e elocutivo - entre os dois primeiros grupos, que, num exame rápido, conduziria a uma conclusão de equilíbrio, constitui-se numa diferença expressiva. Explica-se: $1^{\circ}$ ) o comportamento delocutivo está em todos os grupos; $2^{\circ}$ ) as ocorrências de comportamento elocutivo se deram predominantemente pela $1^{\mathrm{a}}$ pessoa do plural, pessoa do discurso que torna o texto mais formal do que se se usasse a $1^{\mathrm{a}}$ do singular, portanto menos subjetivo.

Veja-se um exemplo com a $1^{\mathrm{a}}$ pessoa do singular:

"Até o momento em que escrevo, as ditas foices ainda estavam empunhadas."

(Quelônios no Planalto, 21/12/2012)

No recorte, da temática Política, há uma única ocorrência de marca de $1^{a}$ pessoa do singular (escrevo), mas ela é suficiente para fazer sentir a presença do sujeito da enunciação, instância discursiva que corresponde ao sujeito de carne e osso Luiz Garcia. 
Resumindo-se, o cronista produz suas crônicas, valendo-se tanto de uma enunciação delocutiva quanto de uma enunciação elocutiva e alocutiva, apresentando preferência, entretanto, pela primeira. Isso significa, considerando-se o fenômeno do pathos, que a subjetividade do sujeito da enunciação é disfarçada e que as estratégias de patemização têm um nível de elaboração mais alto do que simplesmente apresentar sua opinião de modo explícito (comportamento elocutivo) ou chamar o leitor para o seu texto (comportamento alocutivo).

A segunda hipótese da pesquisa - as marcas verbais que provocariam efeitos patêmicos estariam tanto no grupo de palavras pertencentes a um universo emocional quanto no grupo de palavras não relacionadas a esse universo - foi confirmada. As duas categorias são utilizadas para provocar efeito patêmico.

No que diz respeito à primeira parte da hipótese - as marcas verbais que provocariam efeitos patêmicos estariam no grupo de palavras pertencentes a um universo emocional -, destaca-se a estratégia de patemização palavras que descrevem de maneira transparente emoções (alívio, esperança, certeza, consolo, otimismo, tristeza, preocupação, indignação etc). Sobre elas, chegou-se aos seguintes resultados:

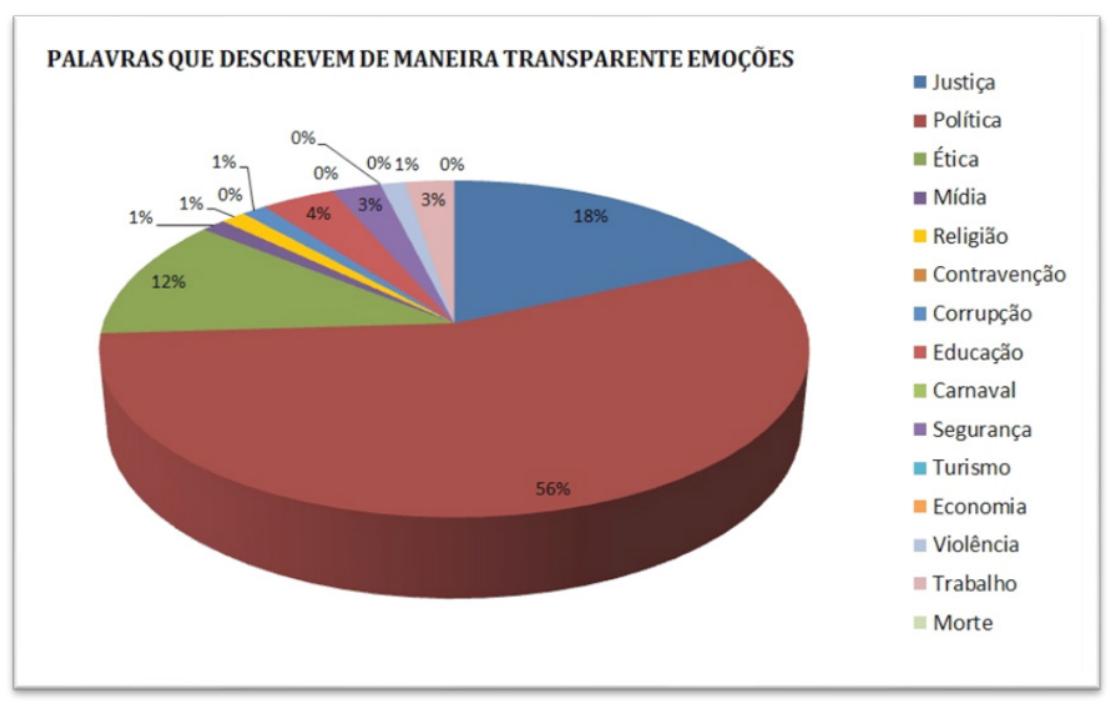

Gráfico 2 
Observa-se, no gráfico (2), que as palavras que descrevem emoções apresentaram uma frequência de $56 \%$ na temática Política, 18\% em Justiça e 12\% em Ética; 4\% em Educação, 3\% em Segurança e Trabalho, $1 \%$ em Mídia, Religião, Corrupção e Violência; 0\% em Contravenção, Carnaval, Turismo, Economia e Morte. Veja-se um exemplo da temática Justiça:

\begin{abstract}
"Não é agradável ficarmos sabendo, [...], que um deputado federal teve o exercício do mandato interrompido por ter sido punido pelo feio crime de botar no bolso dinheiro público. Aconteceu, na semana passada, com Natan Donadon, de Rondônia. [...] Ele é o primeiro deputado a ser preso e condenado por desviar verbas de publicidade da Assembleia Legislativa de Rondônia. [...] Policiais e membros do Ministério Público já manifestaram a esperança de que seu caso abra caminho para a punição de políticos de outros estados que tenham cometido." (Celas, 02/07/2013)
\end{abstract}

Este recorte apresenta o substantivo esperança, palavra que pertence a um universo emocional, que descreve um sentimento: o sentimento de esperança. Ao descrever um sentimento, provoca no leitor uma dada emoção. No caso em apreço, o cronista, ao relatar que policiais e membros do M.P. manifestaram esperança de que outros políticos criminosos fossem punidos, provoca no leitor a mesma emoção de esperança. O leitor elabora, em fração de segundos, o seguinte raciocínio: se os policiais e o MP estão com esperança de que outros sejam punidos a partir do exemplo do que ocorreu com Donadon, então eu também tenho esperança.

Vale chamar a atenção, aqui, para o que diz Parret (1997, p. 113), em seu texto intitulado "O pathos razoável". Para ele, as emoções têm um lado de racionalidade, racionalidade que está presente nas próprias estratégias de sua expressão ou designação. A racionalidade das emoções está presente, por exemplo, no fato de elas serem justificáveis e, às vezes, até desejáveis.

Observe-se que, no trecho em estudo, o leitor da crônica passa a ter esperança de que outros políticos sejam punidos, depois de tomar ciência de que profissionais (e não pessoas quaisquer) como policiais e membros do M.P. manifestaram esperança. Isso significa que a esperança do leitor tem justificativa ("Eu tenho esperança, pois policiais e membros 
do MP têm esperança!"), e que é também desejada por ele. O leitorcidadão quer ter esperança, na medida em que deseja que a impunidade com relação aos políticos tenha fim. É importante assinalar que se está considerando, aqui, o leitor cujos valores vão ao encontro do sentimento de esperança. Se se tratar de alguém cujos valores são diferentes, a palavra esperança pode provocar um outro sentimento, como o de preocupação, por exemplo.

Com relação aos percentuais de uso de palavras que descrevem emoção, destaca-se a frequência de $56 \%$ na temática Política, estando o segundo e o terceiro lugares bem distantes $-18 \%$ em Justiça e $12 \%$ em Etica. A Política é uma temática bastante polêmica por sua própria natureza, mas esse assunto será tratado mais à frente.

Quanto à segunda parte da segunda hipótese - palavras não relacionadas a um universo emocional também produziriam efeitos patêmicos -, sobressai-se a estratégia de patemização palavras/ expressões que desencadeiam emoção. Veja-se o gráfico:

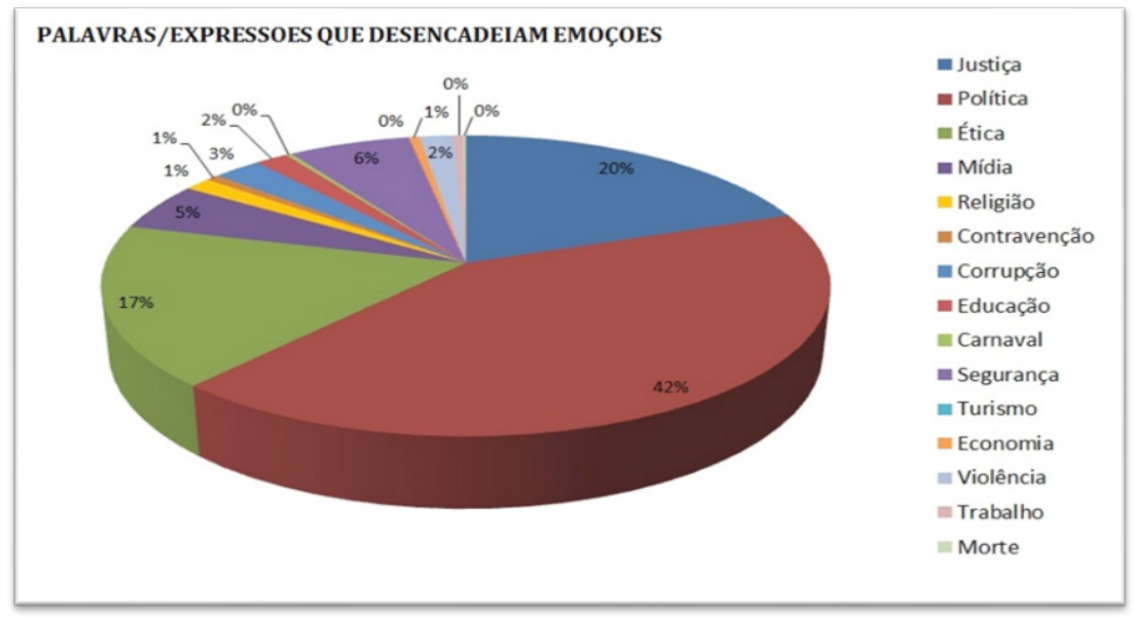

Gráfico 3

Como se pode observar no gráfico (3), a estratégia palavras/ expressões que desencadeiam emoção apresentou uma frequência de $42 \%$ na temática Política, 20\% em Justiça, 17\% em Ética; 6\% em Segurança, 5\% em Mídia, 3\% em corrupção, 2\% em Violência e Educação, 1\% 
em Religião, Contravenção e Economia; e 0\% em Carnaval, Turismo e Morte. Veja-se um exemplo da temática Política:

“O Brasil vive obviamente uma crise social e política, como
não se via há muito tempo [...]. Seria perigosa ingenuidade
limitar as suas origens à questão das passagens de ônibus
urbanos. Ela foi o ponto de partida - um modesto estopim,
pode-se dizer - para uma explosão urbana como não se
via há muito tempo. E que, pelo visto, estava esperando
um pretexto para acontecer." (Perigosa perplexidade,
25/06/2013)

No recorte em apreço, identificam-se 3 ocorrências de expressões que não pertencem a um universo emocional, mas que desencadeiam emoção no contexto em que se encontram. São elas: crise social e política; passagens de ônibus urbano; explosão urbana.

O Brasil, na ocasião em que a crônica foi publicada, passava por um momento muito delicado, que dizia respeito à ocorrência de passeatas por várias cidades do país. Os movimentos protestavam contra a subida do preço das passagens de ônibus e reivindicavam a permanência do passe livre nos ônibus urbanos para estudantes e idosos. Aconteceu, entretanto, que se juntaram, às pessoas sérias e bem intencionadas, criaturas radicais e baderneiras, provocando pânico, ao tentar, por exemplo, invadir e incendiar o Itamaraty em Brasília, invadir a sede da prefeitura no Rio de Janeiro e praticar violência contra prédios públicos.

Nesse contexto, Garcia usa, em sua crônica, a expressão crise social e política, o que pode ter provocado um sentimento de apreensão no leitor, na medida em que o caos que todos observavam nas ruas estava sendo traduzido e verbalizado pelo cronista: a sociedade estava em crise; a política estava em crise. O que viria depois? No mesmo recorte, utiliza o sintagma passagens de ônibus urbanos, que pode ter levado o leitor a um sentimento de angústia por fazê-lo lembrar-se da violência nas ruas. O sintagma explosão urbana pode tê-lo conduzido para um sentimento de medo em relação à violência que campeava nas grandes cidades.

Com relação aos percentuais de uso dessas palavras/expressões que desencadeiam emoção, assinala-se a frequência de $42 \%$ na temática Política, de $20 \%$ em Justiça e $17 \%$ em Ética. A Política, mais uma vez, destaca-se das demais temáticas, dado que será comentado 
posteriormente. A seguir, veja-se a abordagem sobre o percentual das estratégias como um todo.

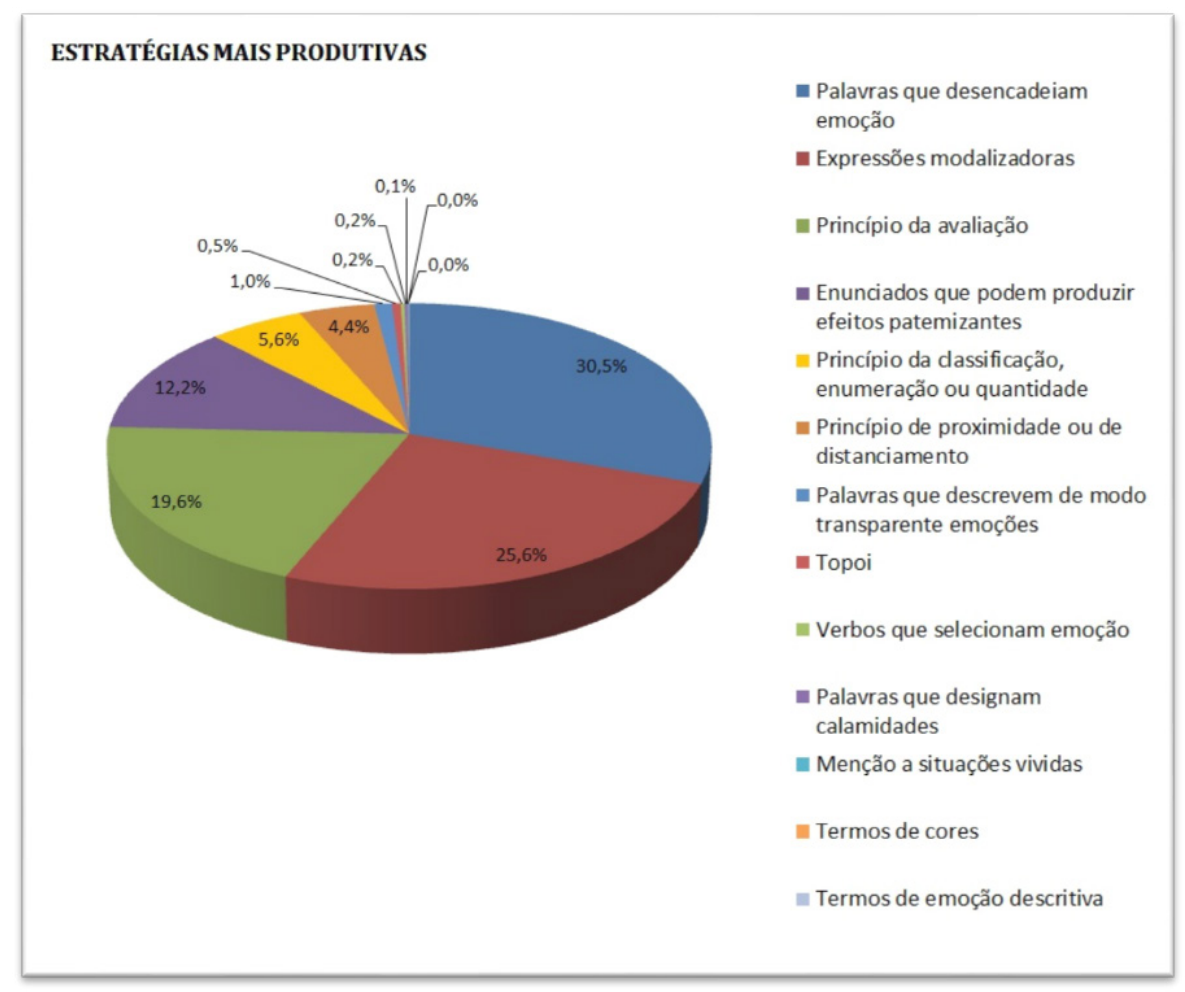

\section{Gráfico 4}

Considerando-se a representação das estratégias, no corpus como um todo, isto é, sem se levar em conta as temáticas, vê-se que a estratégia mais produtiva nos textos de Garcia são as palavras/expressões que desencadeiam emoções, com uma frequência de 30,5\%. A seguir, vêm as expressões modalizadoras, com $25,6 \%$, o princípio da avaliação, com $19,59 \%$, os enunciados que podem produzir efeitos patemizantes, com $12,18 \%$, o princípio da classificação, enumeração ou quantidade, com 5,57\%, o princípio de proximidade ou de distanciamento, com 4,41\%, as palavras que descrevem de modo transparente emoções, com 1,02\%, os topoi, com $0,51 \%$, os verbos que selecionam emoções, com $0,21 \%$, as palavras que designam calamidades, com 0,19\%, a menção a situações 
vividas, $0,05 \%$, os termos de cores, com $0,02 \%$, e os termos de emoção descritiva, com $0,02 \%$.

Eis um exemplo da estratégia mais utilizada por Garcia, as palavras/expressões que desencadeiam emoções (30,5\%):

"Países europeus e americanos aparentemente cuidam apenas de tirar os jovens delinquentes das ruas pelo maior tempo possível. O que talvez possa recuperar alguns mas também pode torná-los criminosos, digamos sem qualquer esforço de humor negro, mais eficientes." (Duas apostas, 07/05/2013)

Os sintagmas jovens delinquentes e criminosos mais eficientes constituem expressões que podem provocar emoção, sobretudo num contexto que trata de adolescentes que cometem crimes. A primeira tem potencial para produzir um sentimento de tristeza, na medida em que é nos jovens que está a esperança de um futuro promissor e mais justo. A segunda pode conduzir a um sentimento de medo, pois, ao mesmo tempo em que a sociedade é preservada do convívio com esses criminosos, estando eles na cadeia, ela corre o risco de eles, na convivência com outros delinquentes, aprimorar sua capacidade de praticar o mal e se tornar um perigo maior para todos e para eles mesmos.

Veja-se, agora, um exemplo da segunda estratégia mais produtiva nos textos do cronista, as expressões modalizadoras $(25,6 \%)$ :

"O nosso Estatuto da Criança e do Adolescente prevê uma pena máxima de três anos de internação; em países europeus e das Américas, menores de 18 anos podem pegar 15 anos de cadeia.

Num rol de 17 países, apenas Brasil e Alemanha aplicam o teto de três anos. É uma diferença considerável, indício seguro que um dos critérios está errado.

Os nossos índices de criminalidade juvenil sugerem [...] que está na hora de rever nossos índices.

Talvez não seja má ideia um estudo suplementar [...]." (Duas apostas, 07/05/2013)

No recorte em destaque, observa-se que o cronista está discutindo a problemática do Estatuto da Criança e do Adolescente no Brasil, estatuto que prevê uma pena máxima de 3 anos de internação, enquanto em outros países os menores de 18 anos podem pegar 15 anos de cadeia. Nesse 
contexto, ele diz que "Num rol de 17 países, apenas Brasil e Alemanha aplicam o teto de três anos."

Assinala-se, aqui, o operador argumentativo apenas, que, para Ducrot (1987, p. 173), é um operador que aponta para a negação da totalidade. A totalidade seriam os 17 países, constituindo, os 2 países, Brasil e Alemanha - a negação da totalidade. Assim, se apenas 2 países aplicam o teto de 3 anos, conclui-se que são poucos os países com essa conduta; se são poucos os países que adotam teto de 3 anos e muitos os que adotam teto de 15 anos, então o teto de 3 anos talvez seja o menos eficiente. A partir desse raciocínio, elaborado pelo leitor, desponta, nele, um sentimento de dúvida: o que está errado, tendo em vista que os índices de criminalidade juvenil no país são altos?

Assim, considerando-se os operadores argumentativos como marcas linguísticas da enunciação e, portanto, uma expressão modalizadora, vê-se que o operador apenas pode suscitar uma emoção, isto é, provocar um efeito patêmico que, no caso, pode ser o de dúvida.

Ainda no mesmo recorte, Garcia, acrescenta que está na hora de rever os índices de criminalidade juvenil e que "Talvez não seja má ideia um estudo suplementar [...]". Verifica-se que o enunciado em destaque pode ser dividido em dois segmentos: o advérbio modalizador talvez e o conteúdo proposicional não é má ideia um estudo suplementar. O advérbio justamente expressa a opinião do locutor sobre aquilo que ele diz: a opinião de não ser má ideia um estudo suplementar é posta sob a modalidade da dúvida. Como o próprio cronista revela dúvida, é natural que o leitor também se sinta em dúvida, efeito patêmico despertado pela expressão modalizadora talvez.

A seguir, veja-se um exemplo da terceira estratégia mais produtiva nos textos do cronista, o princípio da avaliação (19,59\%):

\footnotetext{
"Os nossos índices de criminalidade juvenil sugerem [...] que está na hora de rever nossos índices.

Talvez não seja má ideia um estudo suplementar: acompanhar por um tempo razoável o comportamento de um grupo selecionado segundo critérios óbvios organização familiar, comunidade de moradia etc. [...]" (Duas apostas, 07/05/2013)
}

Neste trecho, o cronista propõe que, além de se reverem os índices de criminalidade, fizesse-se um estudo suplementar segundo 
critérios que, para ele, eram óbvios: organização familiar, comunidade de moradia etc. Vê-se, aqui, a avaliação do locutor com relação aos critérios que deveriam nortear o estudo: critérios óbvios. A partir dessa avaliação, ele transmite sua certeza quanto ao modo como deve ser feito o estudo, provocando no leitor um sentimento de confiança em relação ao tratamento dado por ele ao assunto da criminalidade juvenil. "Confiança", pois, é o efeito patêmico provocado pela estratégia de patemização princípio de avaliação.

A terceira hipótese levantada nesta pesquisa - algumas temáticas seriam mais favorecedoras de efeito patêmico do que outras - também foi confirmada. Observe-se o gráfico a seguir:

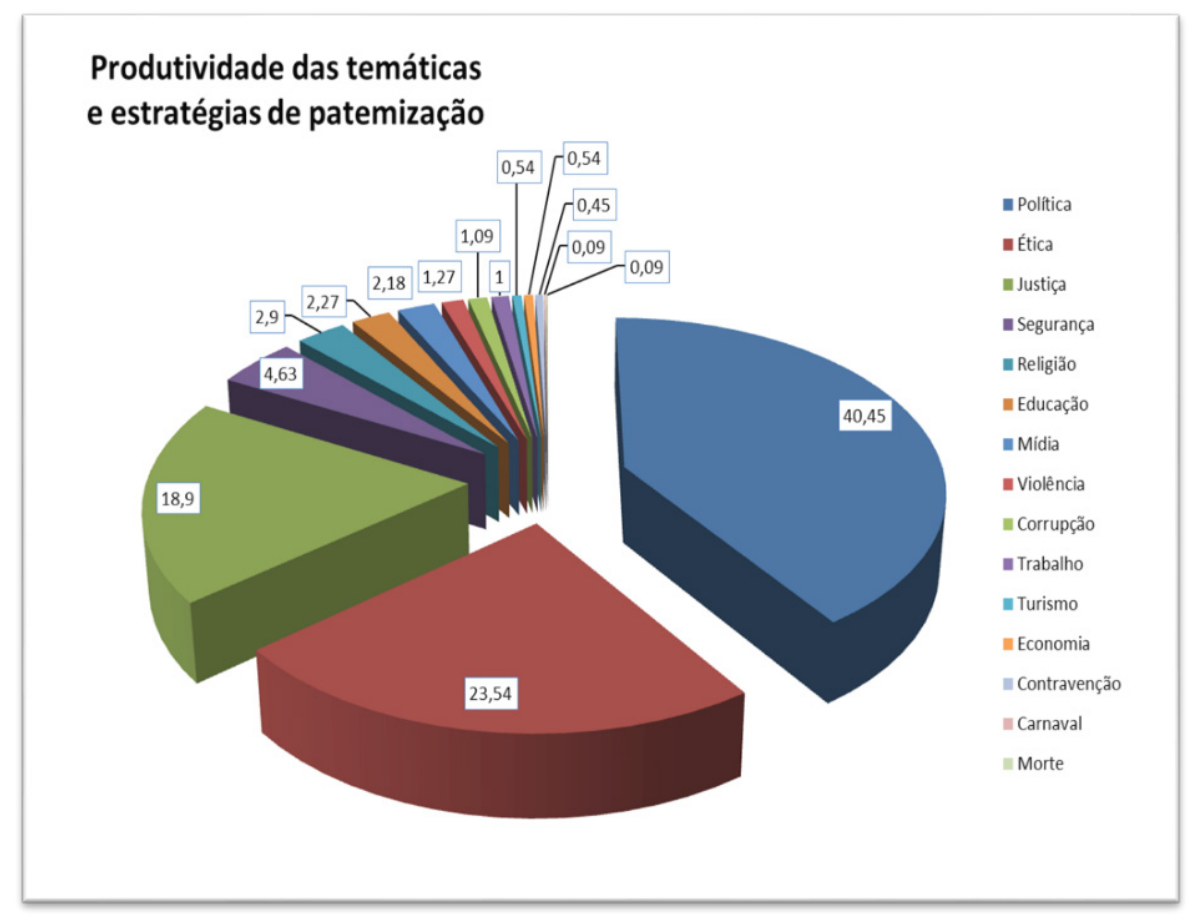

Gráfico 5

A temática mais produtiva quanto às estratégias de patemização foi a Política, com uma frequência de 40,45\%. A seguir, a Ética, com $23,54 \%$ e a Justiça, com 18,90\%. As demais apresentaram um percentual 
baixo: Segurança, com 4,63\%, Religião, com 2,9\%, Educação, com 2,27\%, Mídia, com 2,18\%, Violência, com 1,27\%, Corrupção, com 1,09\% e Trabalho, com 1\%. As temáticas Turismo (0,54\%), Economia (0,54\%), Contravenção $(0,45 \%)$, Carnaval $(0,09 \%)$ e Morte $(0,09 \%)$ obtiveram um percentual insignificante.

Segundo Charaudeau, o campo temático sobre o qual o dispositivo comunicativo se apoia é uma condição a que o efeito patêmico está vinculado. O tema deve prever a existência de um universo de patemização e propor tópicas aptas a provocar um efeito patêmico. A Política é um desses temas intimamente relacionados a um universo de patemização, na medida em que trata de casos que são altamente polêmicos - envolvendo variadas opiniões e até paixões, como os identificados no corpus em estudo - e que acionam tópicas suscetíveis de produzir emoção.

A identificação dessas tópicas, nas crônicas de Garcia, justifica o fato de a Política ter sido a temática mais produtiva em relação às estratégias patemizantes $(40,45 \%)$.

Observe-se, no recorte que se segue, a exploração de duas tópicas - a da atração e a da repulsa (CHARAUDEAU, 2010, p. 53) - aptas a provocar efeito patêmico:

\begin{abstract}
“Tem considerável importância, portanto, que numa recente entrevista o procurador-geral da República, Roberto Gurgel, tenha sentido a elogiável necessidade de cobrar agilidade na execução das penas impostas [...] aos cidadãos (todos da turma de colarinho branco, é bom lembrar) condenados no chamado processo do mensalão. O qual, é sempre bom lembrar, ocupa a vergonhosa posição de maior escândalo político dos últimos anos. Por decisão do STF, última instância do Poder Judiciário, 25 réus foram condenados; 23 receberam penas de prisão, e 11 deles cumprirão a pena, pelo menos inicialmente, em regime fechado." (Sonos tranquilos, 19/03/13)
\end{abstract}

A crônica Sonos tranquilos enaltece a figura do procurador-geral da República, Roberto Gurgel, por ele, publicamente, cobrar agilidade no cumprimento das decisões do tribunal com relação à turma do colarinho branco condenada no processo do mensalão. O procurador se referia ao escândalo do mensalão, processo de corrupção praticado por políticos de vários partidos e tendo como mentor o então Ministro-Chefe da Casa Civil da Presidência da República, José Dirceu. 
Nesse contexto político, Garcia aciona a tópica da atração, ao apresentar a imagem positiva de benfeitor de Roberto Gurgel, que recebe a aprovação do leitor - "ele é admirável". Ao mesmo tempo, Garcia ativa a tópica da repulsa ao referir-se ao processo do mensalão e categorizálo como o maior escândalo político dos últimos anos. Nesse momento, o cronista aponta para a imagem negativa de malfeitor, relacionada aos criminosos, que recebem total desaprovação por parte do leitor - "eles são abomináveis".

Entende-se, então, que os topoi vigentes na cultura dos brasileiros "quem luta contra o crime é admirado" e "quem pratica crimes é abominado" foram os responsáveis pela argumentação engendrada pelo cronista.

Garcia, ao usar a expressão "elogiável necessidade”, estava defendendo a tese - de que tinha considerável importância a atitude do procurador-geral da República de cobrar agilidade na execução das penas -, apoiado no topos segundo o qual "quem luta contra o crime é admirado".

Assim, com as variadas estratégias de patemização presentes no recorte e valendo-se de topoi típicos da cultura brasileira, o cronista desperta efeitos patêmicos.

Outra estratégia de patemização explorada por Garcia, na crônica intitulada Sonhos tranquilos, é a chamada palavras/expressões que desencadeiam emoção - turma do colarinho branco. Veja-se o raciocínio:

$>$ se Gurgel cobrou agilidade na execução das penas impostas aos cidadãos da turma do colarinho branco, então se está fazendo justiça, haja vista o topos que diz, "no Brasil, somente os pobres vão para a cadeia". A conclusão para a qual o sintagma, em seu contexto, apontou, provoca um sentimento de satisfação por parte do leitor, ou ainda, usando-se uma expressão popular brasileira, um sentimento de alma lavada. Destaque-se que a expressão colarinho branco corresponde à única ocorrência, no corpus da pesquisa, da estratégia que pode produzir efeito patêmico chamada termos de cores.

Ainda no recorte em apreço, vale destacar o emprego da estratégia princípio da classificação, enumeração ou quantidade. Essa estratégia apresentou um percentual baixo (5,57\%), mas, nos contextos usados, 
caracterizou-se pela alta possibilidade de emocionar. Quando o cronista diz que 25 réus foram condenados, esse número provoca no leitor um sentimento de prazer, pois, até então, não se havia tido notícia de que qualquer pessoa pertencente ao âmbito da política ou relacionada a esse âmbito tivesse recebido o castigo que merecia ao ser acusada de corrupção.

O mesmo sentimento de prazer é despertado no leitor, quando o cronista informa que 23 receberam penas de prisão, na medida em que, se os 23 roubaram o país, então têm de ser afastados da sociedade da mesma forma que são afastados os criminosos pobres. Ao se deparar, entretanto, com a afirmação de que 11 deles cumprirão a pena em regime fechado, o leitor experimenta um sentimento de frustração, pois, se somente 11 ficarão impedidos de conviver com a sociedade, então mais da metade terá condições de continuar infringindo, de alguma maneira, as regras de convívio social. Deve-se ressaltar, mais uma vez, que o sentimento provocado dependerá do auditório e de seus valores.

A temática Ética se apresentou como a segunda mais produtiva quanto ao uso de estratégias que provocam emoção $(23,54 \%)$. Essa temática trata de questões instigantes, na medida em que tem como ponto central os valores de conduta. Essas discussões, na mídia, têm por objetivo justamente chamar a atenção do leitor sobre o quanto determinados segmentos da sociedade - sobretudo os que ocupam os primeiros escalões - estão desviados dos valores que ainda norteiam a cultura do próprio país.

Veja-se um exemplo ligado à falta de ética na política, trecho em que a tópica da repulsa também é explorada.

"O que se espera de um advogado de defesa, num processo criminal, é que faça o possível para livrar seu cliente de uma condenação.

Quando o acusado é político praticante, há também a expectativa de que a defesa prove - ou faça o possível para isso - que o acusado é cidadão de honestidade impecável [...].

Tudo isso é óbvio e sabido. Mas também se presta a uma afirmação do advogado Marcelo Bessa, em sessão do Supremo Tribunal Federal, que no momento cumpre a dolorosa tarefa de julgar o escândalo do mensalão. Para quem já esqueceu, trata-se do desonesto esquema 
de financiamento das ambições eleitorais de membros e aliados do PT com recursos obtidos por um grupo comandado por José Dirceu, principal estrategista do PT no governo Lula. O mensalão está em julgamento no STF. Foi lá que o advogado Marcelo Bessa, [...], defendeu a tese de que o mensalão foi uma iniciativa que nada tinha de ilegal: era apenas imoral. (Imoral e ilegal, 17/08/2012)."

A crônica Imoral e ilegal trata de uma afirmação feita por um advogado do PR - partido político a que, segundo Garcia, “em 2002 o PT presenteou com R $\$ 20$ milhões supostamente para atender a despesas eleitorais" - sobre o escândalo do mensalão.

Identificam-se três estratégias de patemização: princípio de avaliação (dolorosa tarefa; desonesto esquema); palavra que desencadeia emoção (mensalão); e enunciado que pode produzir efeitos patemizantes (defendeu a tese de que o mensalão foi uma iniciativa que nada tinha de ilegal: era apenas imoral).

Analisando-se o segmento que representa a estratégia enunciados que podem produzir efeitos patemizantes $(12,18 \%)$, observa-se o relato do cronista, segundo o qual o advogado "defendeu a tese de que o mensalão foi uma iniciativa que nada tinha de ilegal: era apenas imoral".

O leitor, ao se deparar com o enunciado, fica impactado com a falta de ética do advogado. Esse fato provoca-lhe um sentimento de indignação, de revolta, sentimento desencadeado pelo enunciado que pode produzir efeito patemizante. Se o advogado defendeu a tese de que o mensalão foi uma iniciativa que nada tinha de ilegal: era apenas imoral, então esse profissional perdeu completamente a noção de certo e de errado, ou seja, a noção dos princípios que norteiam a vida em sociedade.

A quarta hipótese aventada, a de que o efeito visado seria produzido tanto pelo léxico das emoções (substantivos, verbos, adjetivos) quanto pelos enunciados de emoções, também se confirmou.

Quanto ao léxico das emoções, reúnem-se as seguintes estratégias: palavras/expressões que desencadeiam emoção; princípio da avaliação; palavras que descrevem de modo transparente emoções. No que se refere aos enunciados de emoção, tem-se a estratégia enunciados que podem produzir efeitos patemizantes.

Observe-se o gráfico 6: 


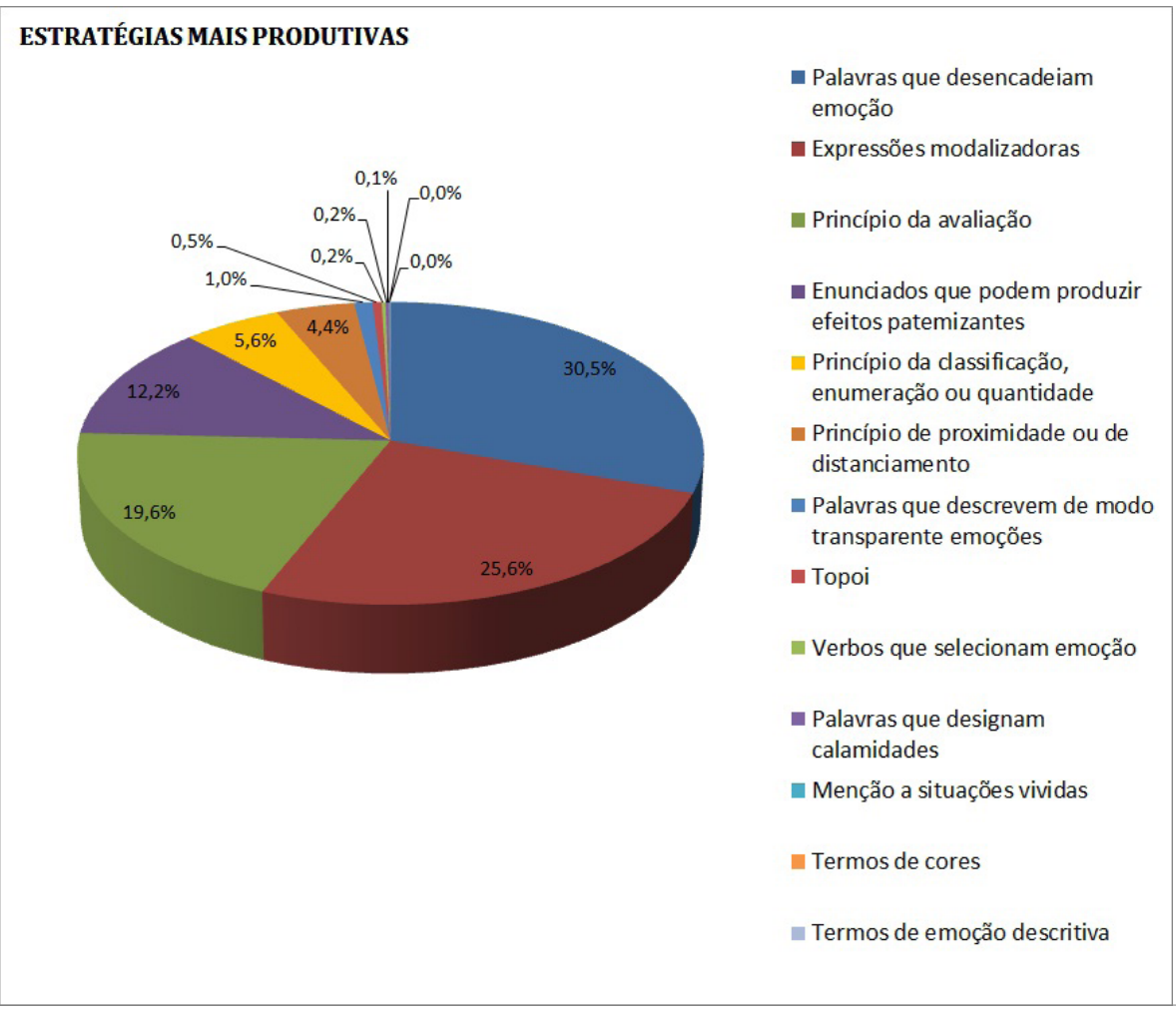

\section{Gráfico 6}

Por meio do gráfico 6, verificam-se as palavras/expressões que desencadeiam emoção em $1^{\circ}$ lugar (30,5\%), o princípio da avaliação em $3^{\circ}(19,6 \%)$ e as palavras que descrevem de modo transparente emoções em $7^{\circ}(1 \%)$, na classificação das estratégias mais produtivas. Os enunciados que podem produzir efeitos patemizantes estão em $4^{\circ}$ lugar $(12,2 \%)$. política:

Veja-se o trecho que se segue, cujo texto pertence à temática

"É uma discussão secular e universal: o homossexualismo é opção de vida ou doença? A primeira hipótese vem ganhando aceitação, e já há bastante tempo. Principalmente nos países mais civilizados. No Brasil, pode-se dizer que 
isso também acontece. Mais honestamente: começa a acontecer. [...].

Recentemente, por exemplo, o Conselho Federal de Psicologia - e, portando, o governo - emitiu uma resolução proibindo os profissionais da área de tratarem homossexuais, na chamada 'cura gay', uma expressão obviamente ofensiva, que define o homossexualismo como uma doença, e não aquilo que realmente é: uma opção de

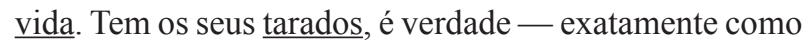
acontece no mundo heterossexual.

Outro dia, veio a reação do outro lado: a Comissão de Direitos Humanos da Câmara aprovou um decreto legislativo em sentido contrário. Era uma iniciativa do seu presidente, o deputado Marco Feliciano.

A 'cura gay' levou paulada de todo lado. [...] o Conselho Federal de Medicina também criticou, com palavras duras.." (A falsa cura, 21/06/2013)

Destacam-se, por exemplo, como palavras/expressões que desencadeiam emoções os sintagmas discussão secular e universal, homossexualismo, opção de vida, doença. Observe-se o raciocínio que pode ser formulado pelo leitor:

Se a dúvida de o homossexualismo ser uma opção de vida ou uma doença é uma discussão secular e universal, então essa dúvida sempre existiu em todos os cantos do planeta e não está resolvida até hoje. A partir desse raciocínio, é natural que o leitor experimente um sentimento de dúvida também.

Observando-se, porém, os índices de avaliação expressão obviamente ofensiva e palavras duras, vê-se um posicionamento mais claro do cronista quanto à questão. $\mathrm{O}$ seu discurso aponta para raciocínios do tipo "se a expressão cura gay é obviamente ofensiva, então o homossexualismo não é uma doença"; "se a expressão foi criticada pelo Conselho Federal de Medicina com palavras duras, mais uma vez conclui-se que o homossexualismo não é uma doença". Essas formulações podem provocar no leitor um sentimento de certeza, certeza essa que é, inclusive, reforçada pelo emprego do advérbio modal realmente (estratégia expressão modalizadora) em "[...] e não aquilo que realmente é: uma opção de vida". Não se pode deixar de assinalar, entretanto, que o auditório não é inerte, na medida em que avalia o que 
lhe é proposto, podendo aderir completamente, parcialmente, ou recusar a orientação argumentativa do discurso.

Quanto à parte da quarta hipótese que diz que o efeito visado seria também produzido pelos enunciados de emoções, vê-se a sua confirmação por meio do enunciado que pode produzir efeitos patemizantes " $\mathrm{A}$ "cura gay" levou paulada de todo lado". A partir dele, o raciocínio do leitor poderia ser este: se A “cura gay" levou paulada de todo lado, então é certo que o homossexualismo não é uma doença.

A quinta hipótese elaborada - orações modalizadoras, advérbios modais, verbos modais e operadores argumentativos constituiriam estratégias produtivas para alcançar efeitos patêmicos - também foi confirmada.

As quatro categorias gramático-discursivas - é pena que; obviamente; pode-se dizer; inclusive -, sob a rubrica "expressões modalizadoras", foram bastante utilizadas, ocupando o $2^{\circ} \operatorname{lugar}(25,6 \%)$ na classificação das estratégias mais produtivas como um todo. Veja-se, agora, cada uma separadamente:

\section{TIPOS DE EXPRESSÕES MODALIZADORAS}

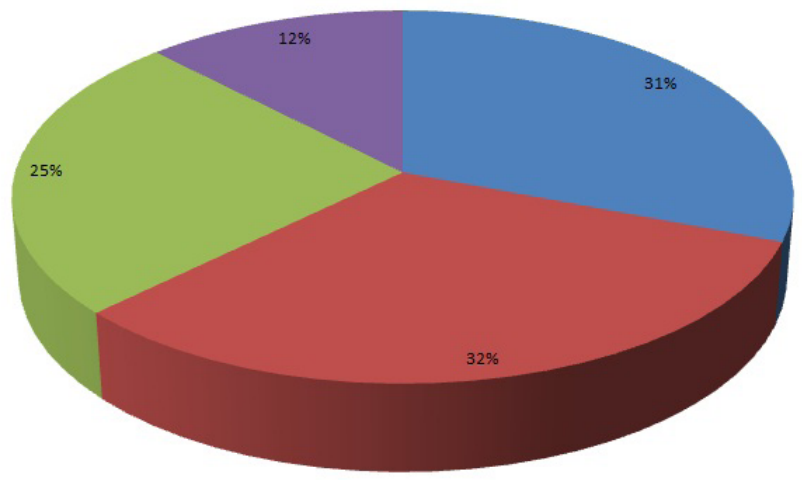

- Expressões adverbiais modais n Operadores argumentativos - Orações modalizadoras - Verbos modais

Gráfico 7 
Os operadores argumentativos apresentaram uma frequência de $32 \%$; as expressões adverbiais modais, $31 \%$; as orações modalizadoras, $25 \%$; e os verbos modais, $12 \%$.

Os operadores argumentativos (32\%) desempenham uma função muito importante no texto, seja do ponto de vista semântico, seja do ponto de vista discursivo. Se se tratar de conectores (portanto, embora, porque etc.), semanticamente, tornam explícita uma relação de sentido entre as orações; discursivamente, introduzem enunciados que funcionam como argumentos que apontam para determinada conclusão, ou introduzem tese. Se se tratar de advérbios ou palavras cuja classe gramatical é incerta ou que não foram encaixadas em nenhuma classe pela GT (inclusive, exceto, apenas etc), semanticamente expressam um determinado sentido - de inclusão, de exclusão, de diminuição, por exemplo - e discursivamente também introduzem argumentos que orientam para determinada conclusão. Dessa forma, é natural que os operadores argumentativos constituam uma estratégia produtiva. Vejase este exemplo:

'Tem sido frequente na mídia a discussão sobre virtudes e defeitos do nosso sistema penal. Com ênfase nos defeitos. Dois exemplos, colhidos nos jornais dos últimos dias: o primeiro é a constatação de que somos talvez generosos demais com adolescentes que cometem crimes graves, inclusive homicídios." (Duas apostas, 07/05/2013)

$\mathrm{O}$ operador inclusive, que semanticamente tem o valor de inclusão, discursivamente introduz o argumento mais forte de uma escala de argumentos que apontam para dada conclusão. No recorte em apreço, a tese de que o nosso sistema penal tem defeitos é defendida por um exemplo retirado de jornal segundo o qual se constatou que somos talvez generosos demais com adolescentes que cometem crimes graves, inclusive homicídios. Observa-se que ser generoso demais com quem comete crimes graves (argumento menos forte) pode causar problemas. Ser generoso demais com quem comete homicídios (argumento mais forte), então, pode provocar problemas maiores ainda. Assim, conclui-se que o sistema penal brasileiro tem defeitos, conclusão que pode orientar o leitor para um sentimento de insegurança.

As expressões adverbiais modais (31\%) também apresentaram uma ótima frequência, e isso se deve ao fato de se constituírem de 
advérbios ou locuções que expressam o ponto de vista do enunciador sobre o teor daquilo que ele diz. Constituem um modo de expressar a subjetividade do sujeito da enunciação. Em se tratando do gênero em estudo - a crônica jornalística -, é natural que a subjetividade esteja presente.

Veja-se um exemplo:

"Ninguém no governo fala em aplicar venda e mordaça nos meios de comunicação. Claro: isso seria antidemocrático, coisa de quem tem medo da verdade. O que se discute nos gabinetes de Brasília é simplesmente - se é que o advérbio pode ser aplicado a questão obviamente complexa - o estabelecimento de um 'marco regulatório da mídia'. Trata-se de uma proposta do PT apoiada, com indisfarçável entusiasmo, por pelo menos dois ministros que dão expediente no Palácio do Planalto: [...].” (O marco, $06 / 09 / 2011)$

Observa-se, no recorte, o uso da expressão adverbial modal obviamente, modificando o adjetivo complexa. O cronista, ao discutir uma proposta do PT de instalar um marco regulatório na mídia, declara que se trata de uma questão não só complexa, mas obviamente complexa. Isso significa que, em sua opinião - e não necessariamente na de outros - é indiscutível a complexidade da implantação de um marco regulatório na mídia. Com essa certeza em suas palavras, o leitor tenderá a dar-lhe razão e, consequentemente, tenderá a experimentar um estado de alerta.

As orações modalizadoras (25\%), como estratégia de patemização, apresentaram um percentual um pouco menor, provavelmente por se constituírem em construções sintáticas complexas - correspondem, normalmente, a uma oração principal em que se encaixam orações subordinadas completivas. De qualquer forma, tiveram uma boa representatividade. Veja-se o exemplo a seguir:

“[...] reportagem da 'Veja' desta semana: segundo a revista, o próprio Lula teria procurado ministros do Supremo Tribunal Federal com uma oferta marota: em troca de um adiamento do julgamento do mensalão - para depois das eleições de outubro, pelo menos - ele protegeria o ministro Gilmar Mendes de boatos sobre mordomias que teria 
recebido do bicheiro Carlinhos Cachoeira numa viagem a Berlim.

Gilmar confirmou ter encontrado o bicheiro na Alemanha, mas acrescentou ter dispensado, com a necessária indignação, a necessidade de qualquer proteção petista para a história das mordomias.

De tudo isso, o que sobra para ser esclarecido é a possível gafe de Lula. Não há dúvida de que ele conversou com o ministro do STF. E é óbvio que o PT tem razões de sobra para desejar uma decisão favorável - ou, pelo menos, pouco dolorosa - dos ministros sobre o desagradável (se é aceitável este eufemismo) episódio do mensalão." (Longe dos bicheiros, 29/05/2012)

No trecho em apreço, observam-se duas ocorrências de orações modalizadoras: Não há dúvida de que e é óbvio que. Ambas expressam a mesma modalidade, a da certeza, o que significa que, na opinião de Garcia - e não necessariamente na de outras pessoas -, é fato que Lula propôs ao ministro Gilmar Mendes uma troca de favores: o adiamento do julgamento do mensalão para depois das eleições pela proteção do ministro de boatos sobre mordomias que teria recebido do bicheiro Carlinhos Cachoeira numa viagem a Berlim. Também é fato que o PT tem razões de sobra para desejar uma decisão favorável dos ministros sobre o desagradável episódio do mensalão.

Diante de tantas certezas por parte do cronista, o leitor pode experimentar um sentimento de satisfação - se for contrário aos procedimentos do $\mathrm{PT}$-, ou de contrariedade - se for favorável aos procedimentos -, já que o ex-presidente, ao fazer uma "oferta marota", estaria confessando que o PT estava efetivamente envolvido no esquema do mensalão.

Por fim, no que se refere às estratégias de patemização, os verbos modais $(12 \%=237$ oc.) obtiveram um percentual mais baixo. É possível que a explicação esteja nos fatos de Garcia comumente mostrar-se categórico em relação às suas afirmações e de fazer isso se utilizando fartamente de expressões adverbiais modais (596 oc.) (obviamente, 59 oc.; certamente, 40 oc.). Quando abrandava o sentido de uma assertiva, usava preferencialmente os verbos modais (poder, parecer) no lugar de expressões adverbiais como "possivelmente (8 oc.)" etc. Como a sua 
tendência é ser bem mais categórico do que conciliador, entende-se o percentual mais baixo dos verbos modais.

Veja-se este exemplo:

"Ela (Dilma) propôs à plateia um pacto nacional em cinco áreas: responsabilidade fiscal, reforma política, saúde, educação e transportes públicos. E mais um plebiscito sobre a criação de uma assembleia constituinte destinada a fazer uma reforma política.

Tudo isso parece ser realmente necessário. Inclusive a promessa de investimento pesado em transportes públicos $[\ldots] "$

No recorte em análise, observa-se uma ocorrência do verbo modal "parecer" seguido do infinitivo "ser". Por meio da locução (seguida de "realmente"), verifica-se o emprego da modalidade da probabilidade no que diz respeito à real necessidade das medidas propostas pela presidente. A probabilidade verbalizada pelo cronista pode provocar no leitor um sentimento de otimismo quanto à perspicácia da Presidente.

Levando-se em conta a pesquisa como um todo, encerram-se aqui as principais informações e discussões realizadas. A seguir serão arroladas as principais conclusões.

\section{Considerações finais}

Este artigo apresentou os resultados de uma pesquisa que estudou o processo de patemização em crônicas jornalísticas escritas por Luiz Garcia. Para isso, valeu-se da visão de Patrick Charaudeau e de Christian Plantin sobre a temática, bem como de trabalhos de outros estudiosos acerca dos conceitos de enunciação e modalização.

A análise do corpus orientou-se pelos conceitos emitidos pelos linguistas e por cinco hipóteses aventadas, as quais serão comentadas na sequência.

A primeira hipótese postulou que o efeito patêmico se apresentaria tanto por meio de uma enunciação da expressão patêmica (alocutiva e elocutiva) quanto por meio de uma enunciação da descrição patêmica (delocutiva), havendo, porém, predomínio desta. A sua confirmação, representada no gráfico 1 , mostrou a presença dos dois tipos de enunciação e indicou o predomínio da segunda, na medida em que o comportamento delocutivo esteve presente em todos os grupos. 
A segunda hipótese da pesquisa, de acordo com a qual as marcas verbais que provocariam efeitos patêmicos estariam tanto no grupo de palavras pertencentes a um universo emocional quanto no grupo de palavras não relacionadas a esse universo, também foi confirmada. As duas categorias são utilizadas para provocar efeito patêmico, sendo, a primeira, representada pela estratégia de patemização "palavras que descrevem de maneira transparente emoções" (gráfico 2), e a segunda, pela estratégia "palavras/expressões que desencadeiam emoção" (gráfico 3).

Considerando-se a representação das estratégias, no corpus como um todo - sem interferência das temáticas - pode ser observada (gráfico 4) a produtividade de todas as estratégias, destacando-se como mais produtiva a chamada "palavras/expressões que desencadeiam emoções".

A terceira hipótese levantada dizia que algumas temáticas seriam mais favorecedoras de efeito patêmico do que outras. O gráfico 5 ilustrou plenamente a sua confirmação, revelando, por exemplo, que a temática Política suplantou as demais quanto à produção de estratégias patemizantes.

A quarta hipótese aventada, a de que o efeito visado seria produzido tanto pelo léxico das emoções quanto pelos enunciados de emoções, também se confirmou. Certamente houve predomínio do léxico das emoções, já que essa categoria foi representada por três estratégias: palavras que desencadeiam emoção; princípio da avaliação; palavras que descrevem de modo transparente emoções. No que se refere aos enunciados de emoção, estes foram representados por uma única estratégia: enunciados que podem produzir efeitos patemizantes. $\mathrm{O}$ gráfico 6 ilustra esses resultados.

A quinta hipótese, de acordo com a qual orações modalizadoras, advérbios modais, verbos modais e operadores argumentativos constituiriam estratégias produtivas para alcançar efeitos patêmicos, foi igualmente confirmada. As quatro categorias, que se reuniram sob a rubrica "expressões modalizadoras", foram muito utilizadas, ocupando o $2^{\circ}$ lugar no gráfico que representou a produtividade das estratégias como um todo. Considerando-se as quatro categorias separadamente, observouse, o predomínio dos operadores argumentativos, seguidos pelos advérbios modais, orações modalizadoras e verbos modais (gráfico 7).

Fecha-se este artigo, que reúne os principais dados da pesquisa, com a convicção de que muito ainda pode ser estudado sobre o processo de patemização e espera-se avançar nessa tarefa, juntamente com os 
orientandos que estão trabalhando com o conceito de pathos aplicado à mídia.

\section{Referências}

ANSCOMBRE, J. C. e DUCROT, O. Deux mais en français. Língua. Amsterdam, n. 43, p. 23-40, 1977.

ARISTÓTELES. Retórica. São Paulo: WMF Martins Fontes, 2012.

CHABROL, C. De l'impression des personnes à 1' expression communicationnelle des émotions. In: PLANTIN, C. et alii. (Org.). Les émotions dans les interactions. Lyon: Presses Universitaires de Lyon, 2000, p. 105-124.

CHARAUDEAU, P. Grammaire du sens et de l'expression. Paris: Hachette, 1992.

CHARAUDEAU, P. Para uma nova análise do discurso. In: CARNEIRO, A.D. (Org.). O discurso da mídia. Rio de Janeiro: Oficina do Autor, 1996. p. 5-43.

CHARAUDEAU, P. Une problématisation discursive de l'émotion: à propos des effets de pathémisation à la télévision. In PLANTIN, C. et alii. (Org.). Les émotions dans les interactions. Lyon, Presses universitaires de Lyon, 2000. p. 124-155.

CHARAUDEAU, P.; MAINGUENEAU, D. Dictionnaire D'Analyse du Discours. Paris: Éditions du Seuil, 2002.

CHARAUDEAU, P. Visadas discursivas, gêneros situacionais e construção textual. In: MACHADO, I. L.; MELLO, R. (Org.). Gêneros: reflexões em Análise do Discurso. Belo Horizonte: NAD - Faculdade de Letras da UFMG, 2004. p 13-41.

CHARAUDEAU, P. Pathos e discurso político. In: MACHADO, I.L.; MENEZES, W.; MENDES, E. (Org.). As emoções no discurso. v. I. Rio de Janeiro: Lucerna, 2007. p. 240-251.

CHARAUDEAU, P. Linguagem e discurso: modos de organização. São Paulo: Contexto, 2008. 
CHARAUDEAU, P. A patemização na televisão como estratégia de autenticidade. In: MENDES, E.; MACHADO, I.L. (Org.). As emoções no discurso. Campinas: Mercado das Letras, 2010. v. II, p. 23-56.

COSTA, S.R. Dicionário de gêneros textuais. Belo Horizonte: Autêntica, 2009.

DUCROT, O. O dizer e o dito. Campinas: Pontes, 1987.

GRICE, H. P. Lógica e conversação. In: DASCAL, M. (Org.). Fundamentos metodológicos da linguística. Campinas: Editora do Autor, 1982. v. IV, p. 81-103.

KERBRAT-ORECCHIONI, C. La enunciación: de la subjetividad en el lenguaje. Buenos Aires: Edicial, 1993.

KOCH, I. V. Argumentação e linguagem. 13. ed. São Paulo: Cortez, 2011.

MAINGUENEAU, D. Doze conceitos em análise do discurso. São Paulo: Parábola, 2010.

MAINGUENEAU, D. Ethos, cenografia, incorporação. In: AMOSSY, R. Imagens de si no discurso: a construção do ethos. 2. ed. São Paulo: Contexto, 2011, p. 69-90.

PARRET, H. O pathos razoável. In: PARRET, H. A estética da comunicação: além da pragmática. Campinas: UNICAMP, 1997. p. 107-130.

PERELMAN, C.; OLBRECHTS-TYTECA, L. Tratado da argumentação: a nova retórica. São Paulo: Martins Fontes, 1996.

PLANTIN, C. A argumentação: história, teorias, perspectivas. São Paulo: Parábola, 2008.

PLANTIN, C. As razões das emoções. In: MENDES, E.; MACHADO, I.L. (Org.) As emoções no discurso. Campinas: Mercado das Letras, 2010. v. II, p. 57-80. 